\title{
PERBANDINGAN POLA SENSITIVITAS BAKTERI TERHADAP ANTIBIOTIK ANTARA RUANG ICU DAN NON ICU DI RUMAH SAKIT UMUM DAERAH Dr. H. ABDUL MOELOEK PROVINSI LAMPUNG PERIODE APRIL - JUNI TAHUN 2019
}

\author{
Hidayat1, Zulhafis Mandala², Joan Willy Ansar'2,Iga Afifah Rahmadini³ \\ ${ }^{1}$ Kepala Instalasi Laboratorium Patologi Klinik RSUD Dr. H. Abdul Moeloek \\ Provinsi Lampung \\ 2Staf Pengajar, Fakultas Kedokteran, Universitas Malahayati, Lampung \\ 3Mahasiswa Kedokteran, Fakultas Kedokteran, Universitas Malahayati, \\ Lampung
}

[email korespondensi: Igaafifah31@gmail.com]

\begin{abstract}
Comparison Of Bacterial Sensitivity Patterns Against Antibiotics Between ICU And Non ICU Spaces In The General Hospital Of Dr. H. Abdul Moeloek Lampung Province Period April-June 2019. Data shows that Lampung province is the second highest level of antibiotics without prescription, namely 92\% after Central Kalimantan (93.4\%). The most bacterial growth is in the ICU room as much as $14.6 \%$. Patients treated in ICU who have low body defenses. to find out whether there are differences in the comparative pattern of bacterial sensitivity to antibiotics in hospitals. Dr. H. Abdul Moeloek Lampung Province. This type of research is descriptive using a retrospective approach. Samples of 244 records medical records in the ICU and non ICU rooms that received antibiotic therapy and had the results of the sensitivity test period April - June 2019, data obtained from the Clinical Pathology Laboratory Dr. H. Abdul Moeloek Lampung Province. Statistical test with univariate test. Based on the culture results of the period April - June 2019 namely in the ICU room there was the highest sample of Enterobacter cloacae 14 (20\%) samples while in the non ICU room is Enterobacter sp $46(26 \%)$ sample. The highest number of bacteria in the ICU room is Enterobacter cloacae with $100 \%$ sensitivity to Amikacin antibiotics while in non-ICU room is Enterobacter $s p$ with $100 \%$ sensitivity to Sulbactam antibiotics.
\end{abstract}

Keyword : Germs pattern, Antibiotics, Intensive Care Unit

\begin{abstract}
Abstrak: Perbandingan Pola Sensitivitas Bakteri Terhadap Antibiotik Antara Ruang ICU Dan Non ICU Di Rumah Sakit Umum Daerah Dr. H. Abdul Moeloek Provinsi Lampung Periode April-Juni Tahun 2019. Data menunjukkan provinsi Lampung tertinggi kedua menyimpan antibiotik tanpa resep yaitu 92\% setelah Kalimantan Tengah $(93,4 \%)$. Pertumbuhan bakteri paling banyak yaitu pada ruang ICU sebanyak $14,6 \%$. Pasien-pasien yang dirawat di ICU yang mempunyai pertahanan tubuh yang rendah. Untuk mengetahui apakah terdapat perbedaan perbandingan pola sensitivitas bakteri terhadap antibiotik di RSUD. Dr. H. Abdul Moeloek Provinsi Lampung.Jenis penelitian ini adalah deskriptif menggunakan pendekatan Retrospekif. Sampel sebanyak 244 catatan rekam medik di ruang ICU dan non ICU yang mendapat terapi antibiotik dan mempunyai hasil uji kepekaan periode April - Juni 2019, data diperoleh dari laboratorium Patologi Klinik RSUD Dr. H. Abdul Moeloek Provinsi Lampung. Uji statistik dengan uji univariat. Berdasarkan hasil kultur periode bulan April - Juni 2019 yaitu di ruang ICU terdapat sampel tertinggi bakteri Enterobacter cloacae 14 (20\%) sampel sedangkan di ruang non ICU yaitu bakteri Enterobacter sp 46 (26\%) sampel. Bakeri terbanyak di ruang ICU yaitu Enterobacter cloacae dengan tingkat kepekaan $100 \%$ terhadap antibiotik Amikacin sedangkan di ruang non ICU yaitu Enterobacter $s p$ dengan tingkat kepekaan $100 \%$ terhadap antibiotik Sulbactam.
\end{abstract}

Kata Kunci : Pola Kuman, Antibiotik, Intesnsive Care Unit 


\section{PENDAHULUAN}

Antibiotik adalah zat kimia yang memiliki khasiat menghambat atau mematikan Pertumbuhan dan perkembangan Mikroorganisme. (Tjay dan rahardja, 2007).

Penggunaan antibiotik yang tidak rasional dapat menyebabkan timbulnya kuman resisten di Rumah sakit terutama di unit perawatan intensif. Kondisi ini diduga disebabkan karena penggunaan antibiotik yang semakin meluas, sehingga sering diberikan tidak proporsional dan rasional baik di rumah sakit maupun di luar rumah sakit. (Yuliani I, 2015).

Menurut Departemen Kesehatan dan Layanan Masyarakat Amerika Serikat yang berbasis di DeKalb County, setiap tahun terdapat dua juta orang yang telah resisten terhadap antibiotik dan setidak nya 23.000 orang meninggal dunia akibat dari resistensi antibiotik Data menunjukkan $86 \%$ rumah tangga menyimpan antibiotik tanpa resep, provinsi Lampung menjadi yang tertinggi kedua yaitu $92 \%$ rumah tangga penyimpan antibiotik setelah Kalimantan Tengah 93,4\%. (Rikesdas, 2013).

Intensive Care Unit (ICU) adalah unit perawatan komprehensif dan dukungan kehidupan untuk pasien yang mengalami luka atau sakit yang parah. (WHO, 2015).

Dari data yang didapatkan yang memiliki pertumbuhan paling banyak yaitu pada ruang ICU sebanyak $14,6 \%$. Kuman paling banyak ditemukan di ruang ICU karena banyak ditemukan infeksi yang terkontaminasi dengan sumber bakteri patogen, sehingga dapat menimbulkan wabah infeksi. Pasien-pasien yang dirawat di ICU yang mempunyai pertahanan tubuh yang rendah, monitoring keadaan secara invasif, terpapar dengan berbagai jenis antibiotik dan terjadi kolonisasi oleh bakteri resisten. Mengakibatkan pasien yang dirawat mempunyai potensi yang lebih besar mengalami infeksi (Zahra M, 2018).

Penelitian yang dilakukan pada pasien yang dirawat di ICU RSUP
Sanglah Denpasar, mikroorganisme yang banyak ditemui adalah Pseudomonas aeruginosa (18\%), Acinetobacter baumanii $(18 \%)$, Staphylococcus sp $(12 \%)$, Candida sp $(10 \%)$, dan Staphylococcus aureus (8\%). Pada isolat bakteri yang ditemui pada pasien, didapatkan bahwa Vancomycin dan Linezolid merupakan antibiotik yang sensitif untuk melawan infeksi bakteri Gram positif. Untuk mengobati infeksi bakteri Gram negatif, Cefoperazone/Sulbactam,Piperacillin/Ta zobactam, Meropenem, dan Cefepime dapat menjadi pilihan (Ni Nengah DF, 2016).

Berdasarkan data pola kuman di Rumah Sakit Dr. H. Abdoel. Moeloek Bandar Lampung periode Januari - Juli 2016, didapatkan kuman terbanyak di ruangan ICU adalah Staphylococcus $s p$ sebanyak 134 sampel dengan presentase 43,5\%, Pseudomonas $s p$ sebanyak 45 sampel dengan presentase $14,6 \%$, Klebsiella $s p$ sebanyak 65 sampel dengan presentase $21,1 \%$, Proteus $s p$ sebanyak 59 sampel dengan presentase 19,2\%, Escherichia coli sebanyak 5 sampel dengan presentase $1,6 \%$. Berdasarkan hasil uji sensitifitas terhadap antibiotik didapatkan pola bakteri yang sudah resisten adalah Penisilin dengan presentase $(100 \%)$, Ampisilin dengan presentase $(83 \%)$, Amoksilin dengan presentase $(78,6 \%)$, Cefotaxime dengan presentase $(33 \%)$, Tetrasiklin dengan presentase $(28,6 \%)$, Ceftriaxone dengan presentase $(22,7 \%)$ dan Antibiotik yang masih sensitif yaitu, Meropenem dengan presentase(75\%) (Zahra M, 2018).

Pelayanan kefarmasian di rumah sakit perlu ditingkatkan mutunya agar sesuai dengan standar pelayanan kefarmasian dan standar yang berlaku pada akreditasi terkait pelayanan obat, yaitu standar manajemen penggunaan obat. Selama ini, upaya peningkatan kapasitas SDM (Sumber Daya Manusia) di rumah sakit berjalan dengan inisiatif dari rumah sakit maupun Dinas Kesehatan Propinsi/Kab/Kota. (Kemenkes RI, 2018). 
METODE

Penelitian ini dilaksanakan di Ruang Rekam Medik Rumah Sakit Umum Daerah Dr. H. Abdul Moeloek Provinsi Lampung mulai bulan agustus sampai oktober tahun 2019. Penelitian ini termasuk dalam jenis penelitian deskriptif analitik dengan pengambilan data secara retrospektif. Sampel penelitian ini di lakukan dengan cara memilih sebagian dari populasi. Data di analisis dengan menggunakan analisis univariat untuk memperoleh distribusi frekuensi gambaran pola umum dan sensitivitas terhadap antibiotik dan di dapatkan jumlah sampel terbanyak 244.

HASIL

Tabel 1. Distribusi jenis sampel periode April sd Juni $(n=244)$

\begin{tabular}{cccc}
\hline No. & $\begin{array}{c}\text { Jenis } \\
\text { Sampel }\end{array}$ & Jumlah & \% \\
\hline 1 & Pus & 95 & 38,9 \\
2 & Sputum & 64 & 26,2 \\
3 & Urine & 15 & 6,1 \\
4 & Darah & 56 & 22,9 \\
5 & Cairan & 10 & 4,0 \\
6 & Tubuh & 4 & 1,6 \\
\hline & Feses & 4 & 100 \\
\hline
\end{tabular}

Jenis sampel terbanyak yaitu pus sebanyak 95 sampel (38,9\%), dan sampel terkecil adalah feses yaitu 4 sampel dengan persentasi $1.6 \%$.

Tabel 2. Distribusi jumlah pemeriksaan kultur berdasarkan asal ruangan periode April sd Juni $(n=244)$

\begin{tabular}{|c|c|c|c|}
\hline No. & $\begin{array}{c}\text { Jenis } \\
\text { Sampel }\end{array}$ & Jumlah & $\%$ \\
\hline \multirow[t]{4}{*}{ I. } & $\begin{array}{c}\text { RUANG ICU } \\
\text { (Steril) }\end{array}$ & $50(95)$ & 20,4 \\
\hline & PICU & 9 & 3,6 \\
\hline & ICCU & 6 & 2,4 \\
\hline & NICU & 4 & 1,6 \\
\hline \multirow[t]{3}{*}{ II. } & $\begin{array}{l}\text { RUANG NON } \\
\text { ICU (Steril) }\end{array}$ & $175(168)$ & \\
\hline & Perinatal & 30 & 12,2 \\
\hline & Melati & 20 & 8,1 \\
\hline 13 & $\begin{array}{r}\text { Pseudomona } \\
\text { flourescens }\end{array}$ & 2 & 1 \\
\hline
\end{tabular}

\begin{tabular}{ccc} 
IRJ & 16 & 6,5 \\
Kenanga & 13 & 5,3 \\
Mawar & 11 & 4,5 \\
Kutilang & 10 & 4 \\
Murai & 10 & 4 \\
Anyelir & 10 & 4 \\
PBH Lt.2 & 9 & 3,6 \\
Alamanda & 9 & 3,6 \\
PBH Lt.4 & 6 & 2,4 \\
Bougenvil & 6 & 2,4 \\
PBH Lt.3 & 5 & 2 \\
7A & 5 & 2 \\
Gelatik & 4 & 1,6 \\
PBH Lt.1 & 3 & 1.2 \\
Delima & 3 & 1,2 \\
IGD & 2 & 0,8 \\
Kemuning & 1 & 0,4 \\
VIP A & 1 & 0,4 \\
2A & 1 & 0,4 \\
\hline Jumlah (steril) & $\mathbf{2 4 4}$ & $\mathbf{1 0 0}$ \\
\hline
\end{tabular}

Berdasarkan tabel di atas diketahui hasil pemeriksaan menunjukan bahwa dari 69 sampel di ruang ICU, dan non ICU di RSUD Abdul Moeloek Bandar lampung, jenis sampel tertinggi di ruang non ICU adalah ruang Perinatal yaitu 30 sampel $(12,2 \%)$ dan yang terendah adalah ruang kemuning, VIP $A$, dan $2 A$ yaitu masing-masing 1 sampel $(0,4 \%)$, dan ruang ICU yaitu 50 sampel $(20,4 \%)$.

Tabel 3. Distribusi Jenis Bakteri yang tumbuh di Ruang Non ICU $(n=175)$

\begin{tabular}{|c|c|c|c|}
\hline NO. & Nama Bakteri & Jumlah & $\%$ \\
\hline 1 & Enterobacter sp & 46 & 26 \\
\hline 2 & Klebsiella sp & 23 & 13 \\
\hline 3 & Escherichia coli & 20 & 11 \\
\hline 4 & $\begin{array}{c}\text { Klebsiella } \\
\text { pneumoniae }\end{array}$ & 16 & 9 \\
\hline 5 & $\begin{array}{c}\text { Seratia } \\
\text { mercescens }\end{array}$ & 10 & 5 \\
\hline 6 & $\begin{array}{l}\text { Pseudomonas } \\
\text { aeroginosa }\end{array}$ & 9 & 5 \\
\hline 7 & Pseudomonas sp & 9 & 5 \\
\hline 8 & $\begin{array}{c}\text { Staphylococcus } \\
\text { sp }\end{array}$ & 8 & 4 \\
\hline 9 & Proteus sp & 8 & 4 \\
\hline 10 & $\begin{array}{l}\text { Pseudomonas } \\
\text { luteola }\end{array}$ & 2 & 1 \\
\hline 11 & $\begin{array}{c}\text { Acinetobacter } \\
\text { iwoffii }\end{array}$ & 2 & 1 \\
\hline 12 & $\begin{array}{c}\text { Burkholdenia } \\
\text { cepacea }\end{array}$ & 2 & 1 \\
\hline 14 & Salmonella $s p$ & 2 & 1 \\
\hline 15 & Enterobacter & 2 & 1 \\
\hline
\end{tabular}




\begin{tabular}{|c|c|c|c|}
\hline \multicolumn{4}{|c|}{ cloacae } \\
\hline 16 & $\begin{array}{c}\text { Acinetobacter } \\
\text { baumannii }\end{array}$ & 1 & 0,5 \\
\hline 17 & Alcaligenes sp & 1 & 0,5 \\
\hline 18 & $\begin{array}{l}\text { Pseudomonas } \\
\text { mendocina }\end{array}$ & 1 & 0,5 \\
\hline 19 & $\begin{array}{c}\text { Enterobacter } \\
\text { duaceae }\end{array}$ & 1 & 0,5 \\
\hline 20 & $\begin{array}{c}\text { Raoultella } \\
\text { ornithinolytica }\end{array}$ & 1 & 0,5 \\
\hline 21 & $\begin{array}{c}\text { Staphylococcus } \\
\text { pseudintermedius }\end{array}$ & 1 & 0,5 \\
\hline 22 & Kocuria kristinae & 1 & 0,5 \\
\hline 23 & $\begin{array}{l}\text { Proridensia } \\
\text { alcalifaciens }\end{array}$ & 1 & 0,5 \\
\hline 24 & $\begin{array}{c}\text { Pseudomonas } \\
\text { oleoverans }\end{array}$ & 1 & 0,5 \\
\hline 25 & $\begin{array}{c}\text { Salmonella } \\
\text { enterica }\end{array}$ & 1 & 0,5 \\
\hline 26 & $\begin{array}{l}\text { Klebsiella } \\
\text { oxytoca }\end{array}$ & 1 & 0,5 \\
\hline 27 & Proteus mirabilis & 1 & 0,5 \\
\hline 28 & $\begin{array}{c}\text { Norganella } \\
\text { morgani }\end{array}$ & 1 & 0,5 \\
\hline 29 & $\begin{array}{c}\text { Seratia } \\
\text { liquefaciens }\end{array}$ & 1 & 0,5 \\
\hline & Jumlah & 175 & $100 \%$ \\
\hline
\end{tabular}

Berdasarkan tabel di atas diketahui jenis bakteri menunjukan bahwa dari 175 sampel di non ICU di RSUD DR. H. Abdul Moeloek Bandar Lampung, jenis sampel tertinggi adalah bakteri Enterobacter sp yaitu 46 bakteri (26\%), dan yang terendah bakteri Acinetobacter baumannii, Alcaligenes, Pseudomonas mendocina, Enterobacter duaceae, Raouttella ornithinolytica, Staphylococcus pseudintermedius, Kocuria kristinae, Proridensia alcalifaciens, Pseudomonas oleoverans, Salmonella enterica, Klebsiella oxycota, Proteus mirabilis, Norganella morgani dan seratia liquefaciens yaitu 1 bakteri $(0,5 \%)$.

Berdasarkan tabel 4 di bawah diketahui jenis bakteri menunjukan bahwa dari 69 sampel di ICU RSUD Abdul moeloek Bandar lampung, jenis sampel tertinggi adalah bakteri Enterobacter cloacaeyaitu 14 bakteri (20\%), dan yang terendah bakteri Pseudomonas flourescens, Pasteurella pnemutropica, Seratia fonticola, Seratia mercescens, dan Alcaligenes aeruginosayaitu 1 bakteri (1\%).

Berdasarkan tabel 5 di bawah diketahui pola bakteri berdasarkan ruangan menunjukan bahwa dari 20 bakteri di ruang ICU RSUD Abdul
Moeloek Bandar Lampung. Bakteri Enterobacter cloacae memiliki senstivitas tertinggi terhadap antibiotik Amikacin yaitu 13 (100\%).Bakteri Klebsiella sp memiliki sensitivitas tertinggi terhadap antibiotik amikacin dan meropenem yaitu $7(100 \%)$, dan sensitivitas terendah terhadap antibiotik Cefotaximeyaitu 1(100\%). Bakteri Pseudomonas luteola memiliki sensitivitas tertinggi terhadap antibiotik Tazobactam dan Cefepime yaitu 5 $(100 \%)$ dan yang terendah terhadap antibiotik Aztreonam yaitu 1 (25\%).

Bakteri Pseudomonas sp memiliki sensitivitas tertinggi terhadap antibiotik Meropenem dan Sulbactam yaitu 5 dengan persentasi $100 \%$ dan yang terendah yaitu antibiotik Ampisilin, Chloramphenicol, Tetracyclin, Cefotaxime, danPenisilin yaitu 1 dengan persentasi 100\%.Bakteri Klebsiella pneumoniamemiliki sensitivitas tertinggi terhadap antibiotik Amikacin dan seulfamethoxazole yaitu $5(71 \%)$ dan yang terendah yaitu antibiotik Nitrofurantion yaitu 1 dengan persentasi $16 \%$.

Berdasarkan tabel 6 di bawah diketahui pola bakteri berdasarkan ruangan menunjukan bahwa dari 29 bakteri di ruang non ICU RSUD Abdul Moeloek Bandar Lampung. Bakteri Enterobacter sp memiliki sensitivitas tertinggi terhadap antibiotik Sulbactam yaitu 43 (100\%) dan sensitivitas terendah terhadap antibiotik Amoxicillin yaitu 2 (100\%). Bakteri Klebsiella sp memiliki sensitivitas tertinggi terhadap antibiotic Meropenem dan Sulbactam yaitu $21(100 \%)$ dan yang terendah terhadap antibiotic Erytromycineyaitu $1(100 \%)$.

Bakteri Escherichia coli memiliki senstivitas tertinggi terhadap antibiotik Amikacin danTigecyclineyaitu 21(100\%) dan terdapatsensitivitas terendahterhadap antibiotik Tetracyclin yaitu 1 (100\%). Bakteri Klebsiella pneumoniae mempunyai sensitivitas tertinggi terhadap antibiotikAmikacinyaitu 8 (92\%) dan yang terendah yaitu antibiotik Ceftriaxone yaitu 1 (7,5\%). Bakteri Seratia mercescens 
mempunyai terhadap sensitivitas tertinggi antibiotik Amikacin, Ciprofloxaxine, Gentamicin, Tigecycline, dan Seulfamethoxazole
yaitu $10(100 \%)$ dan yang terendah yaitu antibiotik Tazobactam yaitu
5(100\%).Bakteri

aeroginosa memiliki

tertinggi terhadap

Pseudomonas sensitivitas Meropenem yaitu 9 (100\%) dan yang terendah yaitu antibiotik Aztreonamyaitu 5 (71\%).

Tabel 4. Distribusi Jenis Bakteri yang tumbuh di Ruang ICU $(n=69)$

\begin{tabular}{cccc}
\hline No. & Nama Bakteri & Jumlah & \% \\
\hline 1 & Enterobacter cloacae & 14 & 20 \\
2 & Klebsiella pneumonia & 8 & 11 \\
3 & Klebsiella sp & 7 & 10 \\
4 & Escherichia coli & 5 & 7 \\
5 & Pseudomonas sp & 5 & 7 \\
6 & Psedomonas luteola & 5 & 7 \\
7 & Proteus sp & 3 & 4 \\
8 & Acinetobacter baumannii & 3 & 4 \\
9 & Staphylococcus sp & 2 & 2 \\
10 & Moraxella lacunata & 2 & 2 \\
11 & Pseudomonas aeroginosa & 2 & 2 \\
12 & Yersinia kristesennii & 2 & 2 \\
13 & Alcaligenes & 2 & 2 \\
14 & Burkholdenia cepacea & 2 & 2 \\
15 & Enterobacter aeroginosa & 2 & 2 \\
16 & Pasteurella pnemutropica & 1 & 1 \\
17 & Seratia fonticola & 1 & 1 \\
18 & Seratia mercescens & 1 & 1 \\
19 & Pseudomonas flourescens & 1 & 1 \\
20 & Alcaligenes aeruginosa & 1 & 1 \\
\hline \multicolumn{5}{r}{}
\end{tabular}

Tabel 5. Pola resistensi Bakteri Terhadap Antibiotik berdasarkan Asal Ruangan ICU

\begin{tabular}{|c|c|c|c|c|c|c|c|c|c|c|c|}
\hline \multirow[t]{2}{*}{ Kode } & \multirow[t]{2}{*}{ Nama Antibiotik } & \multicolumn{2}{|c|}{ 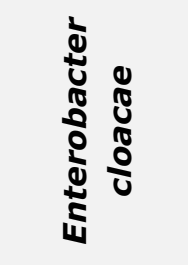 } & \multicolumn{2}{|r|}{$\begin{array}{l}\frac{0}{4} \\
\frac{0}{0} \\
\frac{0}{5} \\
\frac{0}{2}\end{array}$} & \multicolumn{2}{|c|}{ 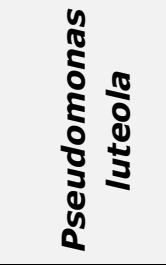 } & \multicolumn{2}{|c|}{ 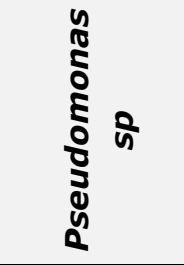 } & \multicolumn{2}{|c|}{ 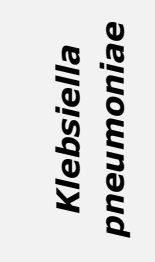 } \\
\hline & & $S$ & $\%$ & $S$ & $\%$ & $S$ & $\%$ & $S$ & $\%$ & $S$ & $\%$ \\
\hline 1 & Ampicilin & 1 & $100 \%$ & & & 0 & $0 \%$ & 1 & $100 \%$ & 0 & $0 \%$ \\
\hline 2 & Sulbactam & 3 & $100 \%$ & 2 & $100 \%$ & 0 & $0 \%$ & 2 & $100 \%$ & 2 & $28 \%$ \\
\hline 3 & Tazobactam & & & & & 1 & $33 \%$ & & & 1 & $14 \%$ \\
\hline 4 & Cefazolin & & & & & & & & & 0 & $0 \%$ \\
\hline 5 & Ceftazidime & & & & & & & & & 0 & $0 \%$ \\
\hline 6 & Ceftriaxone & & & & & & & & & 0 & $0 \%$ \\
\hline 7 & Cefepime & & & & & & & & & 0 & $0 \%$ \\
\hline 8 & Aztreonam & & & & & & & & & 0 & $0 \%$ \\
\hline 9 & Ertapenem & & & & & 1 & $33 \%$ & & & 3 & $42 \%$ \\
\hline
\end{tabular}




\begin{tabular}{|c|c|c|c|c|c|c|c|c|c|c|c|}
\hline 10 & Meropenem & 10 & $100 \%$ & 7 & $100 \%$ & 3 & $100 \%$ & 5 & $100 \%$ & 4 & $57 \%$ \\
\hline 11 & Amikacin & 13 & $100 \%$ & 7 & $100 \%$ & 3 & $100 \%$ & 4 & $100 \%$ & 5 & $71 \%$ \\
\hline 12 & Gentamicin & 9 & $100 \%$ & 2 & $100 \%$ & 1 & $33 \%$ & 4 & $100 \%$ & 4 & $66 \%$ \\
\hline 13 & Ciprofloxaxine & 6 & $100 \%$ & & & 1 & $33 \%$ & 4 & $100 \%$ & 1 & \\
\hline 14 & Tigecycline & & & & & 3 & $100 \%$ & & & 4 & $66 \%$ \\
\hline 15 & Nitrofurantion & & & & & 0 & $0 \%$ & & & 1 & $16 \%$ \\
\hline 16 & seulfamethoxazole & & & & & 0 & $0 \%$ & & & 5 & $71 \%$ \\
\hline 17 & Chloramphenicol & 1 & $100 \%$ & 2 & $100 \%$ & & & 1 & $100 \%$ & & \\
\hline 18 & Tetracyclin & 3 & $100 \%$ & 2 & $100 \%$ & 1 & $100 \%$ & 1 & $100 \%$ & & \\
\hline 19 & Erytromycine & 2 & $100 \%$ & & & & & & & & \\
\hline 20 & Amoxicillin & & & & & & & & & & \\
\hline 21 & Cefotaxime & 1 & $100 \%$ & 1 & $100 \%$ & & & 1 & $100 \%$ & & \\
\hline 22 & Cefadroxile & 1 & $100 \%$ & & & & & & & & \\
\hline 23 & Netilmycin & 9 & $100 \%$ & 2 & $100 \%$ & & & 3 & $100 \%$ & & \\
\hline 24 & Cefoperazone & 5 & $100 \%$ & & & & & 2 & $100 \%$ & & \\
\hline 25 & Penisilin & 2 & $100 \%$ & 3 & $100 \%$ & & & 1 & $100 \%$ & & \\
\hline 26 & Cefpirome & 11 & $100 \%$ & 6 & $100 \%$ & 1 & $100 \%$ & 5 & $100 \%$ & & \\
\hline
\end{tabular}

Tabel 6. Pola resistensi Bakteri Terhadap Antibiotik berdasarkan Asal Ruangan Non ICU

\begin{tabular}{|c|c|c|c|c|c|c|c|c|c|c|c|}
\hline \multirow[t]{2}{*}{ Kode } & \multirow[t]{2}{*}{ Nama Antibiotik } & \multicolumn{2}{|c|}{ 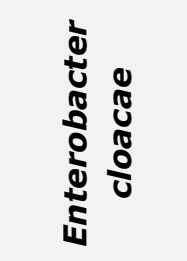 } & \multicolumn{2}{|r|}{$\begin{array}{l}\frac{0}{5} \\
\frac{0}{0} \\
\frac{0}{4} \\
\frac{0}{0} \\
\frac{1}{2}\end{array}$} & \multicolumn{2}{|c|}{ 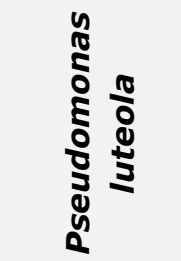 } & \multicolumn{2}{|c|}{$\begin{array}{l}n \\
0 \\
\delta \\
\delta \\
0 \\
0 \\
5 \\
0 \\
0 \\
0\end{array}$} & \multicolumn{2}{|c|}{ 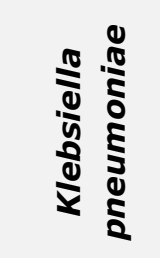 } \\
\hline & & $S$ & $\%$ & $\boldsymbol{S}$ & $\%$ & $\boldsymbol{S}$ & $\%$ & $\boldsymbol{S}$ & $\%$ & $\boldsymbol{S}$ & $\%$ \\
\hline 1 & Ampicilin & 3 & $100 \%$ & & & 2 & $10 \%$ & 0 & $0 \%$ & 0 & $0 \%$ \\
\hline 2 & Sulbactam & 16 & $100 \%$ & 9 & $100 \%$ & 9 & $45 \%$ & 3 & $20 \%$ & 0 & $0 \%$ \\
\hline 3 & Tazobactam & & & & & 19 & $95 \%$ & 4 & $30 \%$ & 5 & $100 \%$ \\
\hline 4 & Cefazolin & & & & & 2 & $10 \%$ & 1 & $8,3 \%$ & 0 & \\
\hline 5 & Ceftazidime & & & & & 8 & $40 \%$ & 3 & $20 \%$ & 9 & $90 \%$ \\
\hline 6 & Ceftriaxone & & & & & 2 & $10 \%$ & 1 & $7,5 \%$ & 9 & $90 \%$ \\
\hline 7 & Cefepime & & & & & 14 & $100 \%$ & 4 & $26 \%$ & 9 & $90 \%$ \\
\hline 8 & Aztreonam & & & & & 5 & $100 \%$ & 3 & $20 \%$ & 9 & $90 \%$ \\
\hline 9 & Ertapenem & & & & & 20 & $95 \%$ & 7 & $50 \%$ & 9 & $100 \%$ \\
\hline 10 & Meropenem & 32 & $100 \%$ & 21 & $100 \%$ & 20 & $95 \%$ & 10 & $66 \%$ & 9 & $90 \%$ \\
\hline 11 & Amikacin & 40 & $100 \%$ & 17 & $100 \%$ & 21 & $100 \%$ & 13 & $92 \%$ & 10 & $100 \%$ \\
\hline 12 & Gentamicin & 28 & $100 \%$ & 17 & $100 \%$ & 15 & $71 \%$ & 5 & $33 \%$ & 10 & $100 \%$ \\
\hline 13 & Ciprofloxaxine & 20 & $100 \%$ & 12 & $100 \%$ & 8 & $38 \%$ & 7 & $50 \%$ & 10 & $100 \%$ \\
\hline 14 & Tigecycline & & & & & 21 & $100 \%$ & 7 & $58 \%$ & 10 & $100 \%$ \\
\hline 15 & Nitrofurantion & & & & & 17 & $80 \%$ & 5 & $55 \%$ & 0 & $0 \%$ \\
\hline 16 & seulfamethoxazole & & & & & 11 & $52 \%$ & 5 & $41 \%$ & 10 & $100 \%$ \\
\hline 17 & Chloramphenicol & 8 & $100 \%$ & 4 & $100 \%$ & & & & & & \\
\hline 18 & Tetracyclin & 6 & $100 \%$ & 9 & $100 \%$ & 1 & $100 \%$ & & & & \\
\hline 19 & Erytromycine & 5 & $100 \%$ & 1 & $100 \%$ & & & & & & \\
\hline 20 & Amoxicillin & 2 & $100 \%$ & & & & & 1 & $100 \%$ & & \\
\hline 21 & Cefotaxime & 9 & $100 \%$ & 5 & $100 \%$ & & & 1 & $100 \%$ & & \\
\hline 22 & Cefadroxile & 9 & $100 \%$ & 4 & $100 \%$ & & & 1 & $100 \%$ & & \\
\hline 23 & Netilmycin & 36 & $100 \%$ & 19 & $100 \%$ & & & 1 & $100 \%$ & & \\
\hline 24 & Cefoperazone & 13 & $100 \%$ & 5 & $100 \%$ & & & & & & \\
\hline
\end{tabular}




\begin{tabular}{llllllllll}
$\mathbf{2 5}$ & Penisilin & 19 & $100 \%$ & 9 & $100 \%$ & & & & \\
$\mathbf{2 6}$ & Cefpirome & 38 & $100 \%$ & 21 & $100 \%$ & 2 & $100 \%$ & 1 & $100 \%$ \\
\hline
\end{tabular}

\section{PEMBAHASAN}

Berdasarkan hasil perbandingan pola sensitivitas bakteri terhadap antibiotik di bagian Mikrobiologi laboratorium Patologi Klinik RSUD DR. $\mathrm{H}$. Abdul Moeloek Provinsi Lampung periode januari-maret tahun 2019 di peroleh kesimpulan sebagai berikut :

Dari hasil penelitian yang dilakukan dengan uji kultur bakteri di Bagian Mikrobiologi Laboratorium Patologi Klinik di RSUD Dr. H. Abdul Moeloek periode April - Juni 2019 menggunakan beberapa jenis spesimen yaitu spesimen Darah, Pus, Sputum, Cairan Tubuh, dan Feses dimana spesimen Pus sebanyak 95 sampel dengan persentase $(38,9 \%)$ dari keseluruhan sampel. Spesimen Sputum sebanyak 64 sampel $(26,2 \%)$, Urin sebanyak 15 sampel $(6,1 \%)$, Darah sebanyak 56 sampel (22,9\%), Cairan Tubuh sebanyak 10 sampel $(4,0 \%)$, dan Feses sebanyak 4 sampel $(1,6 \%)$.

Dapat dilihat bahwa spesimen Pus merupakan spesimen terbanyak pada kultur yang dilakukan di RSUD Dr. $\mathrm{H}$. Abdul Moeloek periode April - Juni 2019. Penelitian ini sesuai dengan penelitian yang dilakukan oleh Gusti Mauladi di RSUD Dr. H. Abdul Moeleok tahun 2018 didapatkan jumlah sampel Pus sebanyak 141 sampel $(47 \%)$, Darah sebanyak 48sampel (16\%), Urin 28 sampel (9\%), Sputum 54 sampel $(18 \%)$, dan Cairan Tubuh 9 sampel (3\%) dan Swab sebanyak 20 sampel (7\%).

Pertumbuhan bakteri yaitu ruang ICU sebanyak 50 sampel $(20,4 \%)$, PICU sebanyak 9 sampel $(3,6 \%)$, NICU sebanyak 4 sampel $(1,6 \%)$, ICCU sebanyak 6 sampel $(2,4 \%)$ dan ruang non ICU terdiri dari ruang Perinatal sebanyak 30 sampel $(12,2 \%)$, ruang Mawar sebanyak 11 sampel (4,5\%), ruang PBH Lt. 1 dan Delima masing- masing sebanyak 3 sampel $(1,2 \%)$, ruang $\mathrm{PBH}$ Lt. 2 dan Alamanda masing-masing sebanyak 9 sampel $(3,6 \%)$, ruang $\mathrm{PBH}$ Lt. 3 sebanyak 5 sampel (2\%), ruang $\mathrm{PBH}$ Lt. 4 dan Bougenvil masing-masing sebanyak 6 sampel $(2,4 \%)$, ruang $7 A$ sebanyak 5 sampel $(2 \%)$, ruang IRJ sebanyak 16 sampel $(6,5 \%)$, ruang IGD sebanyak 2 sampel $(0,8 \%)$, ruang Kutilang, Murai, dan Anyelir masingmasing sebanyak 10 sampel (4\%), ruang Kenanga sebanyak 13 sampel $(5,3 \%)$, ruang Gelatik sebanyak 4 sampel (4\%), ruang Melati sebanyak 20 sampel $(8,1 \%)$, dan ruang VIP $A$, $2 \mathrm{~A}$, dan Kemuning masing-masing sebanyak 1 sampel $(0,4 \%)$. Dari hasil penelitian berdasarkan ruangan yang dilakukan Mutia Zahra tahun 2016 di RSUD Dr. H. Abdul Moeloek didapatkan bakteri terbanyak di ruang ICU yaitu 45 sampel dengan persentase $16,8 \%$, diikuti dengan ruang Kutilang 40 sampel $(12,10 \%)$, ruang Alamanda 39 sampel $(12,7 \%)$, ruang Mawar 27 sampel $(8,8 \%)$, ruang Melati 22 sampel $(7,1 \%)$, ruang Murai dan Gelatik masing-masing sebanyak 18 sampel $(5,8 \%)$.

Pasien - pasien yang dirawat di ICU mempunyai pertahanan tubuh yang rendah, kebersihan perorangan buruk sehingga menciptakan lingkungan yang buruk yang menyebabkan terjadi kolonisasi bakteri, terpapar oleh berbagai antibiotik, penggunan antibiotik yang tidak tepat dan berlebihan dapat menyebabkan bakteri resisten dan kebal terhadap antibiotik tersebut (Zahra, 2016).

Pola kuman terbanyak ditemukan selama periode April - Juni tahun 2019 di RSUD Dr. H. Abdul Moeloek Provinsi Lampung di ruang ICU terbanyak yaitu bakteri Enterobacter cloacae sebanyak 14 sampel (20\%), dan yang terendah bakteri Pseudomonas flourescens, Pasteurella pnemutropica, Seratia fonticola, Seratia mercescens, dan Alcaligenes aeruginosasebanyak 1 sampel(1\%) dan di ruang non ICU jenis sampel tertinggi adalah bakteri Enterobacter spyaitu 46 bakteri dengan persentasi $26 \%$, dan yang terendah bakteri 
Acinetobacter baumannii, Alcaligenes,

Pseudomonas mendocina,

Enterobacter duaceae, Raoultella

ornithinolytica, Staphylococcus

pseudintermedius, Kocuria kristinae,

Proridensia alcalifaciens, Pseudomonas

oleoverans, Salmonella enterica,

Klebsiella oxytoca, Proteus mirabilis,

Norganella morganidan Seratia

liquefacienssebanyak 1 sampel $(0,5 \%)$.

Berdasarkan hasil uji sensitivitas kuman selama periode april - juni tahun 2019 di RSUD Dr. H. Abdul Moeloek Provinsi Lampung yang ditemukan pada penelitian ini didapatkan persentase sensitivitas bakteri terhadap antibiotik yaitu ruang ICU bakteri Enterobacter clocae memiliki sensitivitas tertinggi terhadap antibiotik Amikacin dan sensitivitas terendah terhadap antibiotik Ampicilin, Chloramphenicol, Cefotaxime, dan Cefadroxile sedangkan di ruang non ICU terdapat bakteri Enterobacter $s p$ memiliki sensitivitas tertinggi terhadap antibiotik Amikacin dan sensitivitas terendah terhadap antibiotik Amoxicillin.

Dari hasil penelitian diatas terjadi resistensi bakteri terhadap antibiotik. Hal ini menunjukkan bahwa bakteri yang telah resisten terhadap antibiotik, maka antibiotik tersebut tidak dapat digunakan untuk pengobatan, harus dilakukan pergantian jenis antibiotik agar pengobatan tidak sia-sia. Hal ini menunjukkan masalah resistensi merupakan masalah serius yang harus mendapat perhatian dari semua pihak untuk dapat menghindari dan mengantisipasinya. Bakteri Gramnegatif tersebut mampu membuat mekanisme pertahanan diri terhadap antibiotik, hal ini kemungkinan karena faktor ekstrinsik dan intrinsik. Beberapa hal yang termasuk faktor ekstrinsik adalah penggunaan antibiotik yang salah, pemberian antibiotik yang kurang tepat. Adanya faktor intirinsik mikrobiologi yaitu plasmid medited. Kemampuan bakteri untuk membuat zat metabolit seperti terjadi pada resistensi terhadap Kloramfenikol, Trimetropin disebabkan oleh plasmid mediated (Mauladi, 2019).

\section{KESIMPULAN}

Berdasarkan hasil analisis dan tentang pola dan sensitivitas bakteri terhadap antibiotik di Rumah Sakit Dr. H. Abdul Moeloek periode April-Juni tahun 2019 diperoleh kesimpulan sebagai berikut :

Berdasarkan data pola kuman terbanyak ditemukan selama periode April -Juni tahun 2019 di ruang ICU RSUD Dr. H. Abdul Moeloek adalah Enterobacter cloacae sebanyak 14 (20\%), Klebsiella pneumoniae sebanyak 8 (11\%), Klebsiella $s p$ masing- masing sebanyak 7 (10\%). Sedangkan pola kuman terbanyak yang ditemukan di ruang non ICU adalah Enterobacter $s p$ sebanyak 46 $(26 \%)$, Klebsiella $s p$ sebanyak 23 $(13 \%)$, dan Escherichia coli masingmasing sebanyak 20 (11\%).

Berdasarkan hasil uji sensitivitas kuman selama periode april - juni tahun 2019 di RSUD Dr. H. Abdul Moeloek yang ditemukan pada penilitian ini didapatkan persentase sensitif bakteri terhadap antibiotik sebagai berikut : untuk di ruang ICU ditemukan bakteri Enterobacter cloacae memiliki sensitivitas terhadapantibiotik Amikacin sedangkan untuk yangdi ruang non ICU ditemukan bakteriEnterobacter $s p$ memiliki sensitivitas terhadap antibiotik Sulbactam.

Terdapat perbedaan pola bakteri dan pola sensitivitas bakteri terhadap antibiotik antara ruang ICU dan non ICU periode April - Juni tahun 2019 di RSUD DR.H. Abdul Moeloek Provinsi Lampung.

\section{SARAN}

Perlu dilakukan penelitian tentang pola sensitivitas bakteri di rumah sakit lainnya untuk mengetahui bakteri yang masih sensitif dan bakteri yang sudah resisten terhadap antibiotik.

\section{DAFTAR PUSTAKA}

WHO. 2011. Collaborating Centre for Drug Statistics Methodology. ATC/DDD index 2011. 
Mauladi G. 2019. Analisis Pola Kuman dan Kepekaan Terhadap Antibiotik di Rumah Sakit DR. H. Abdul Moeloek bulan Januari-Maret Tahun 2018. [Skripsi]. Bandar Lampung : Fakultas Kedokteran Universitas Malahayati.

Nengah N, 2016. Pola Mikroba pasien yang dirawat di intensive care unit (ICU). E-jurnal medika 5(4).

Kemnkes RI. 2013. Riset Kesehatan Dasar (Riskesdas). Jakarta.

Tjay H.T, Raharja K. 2007. Obat-obat Penting; Khasiat, Penggunaan, dan Efek Sampingnya, Edisi VI. Jakarta : Elex Media Komputindo.

Yuliani. 2015. Pola resistensi bakteri terhadap antibiotik pada penderita infeksi luka operasi (ilo) di rumah sakit $x$ periode agustus 2013agustus. [Skripsi]. Yogyakarta : Fakultas Farmasi Universitas Gadjah Mada.

Nurmala. 2015. Resistensi dan Sensitivitas bakteri terhadap Antibiotik si RSU dr. Soedarso Pontianak Tahun 2011-2013. eJKI 3(1).

Zahra M. 2018. Analisis pola kuman dan pola resistensi pada hasil pemeriksaan kultur resistensi di laboratorium patologi klinik rumah sakit dr. H. Abdoel moeloek provinsi Lampung periode januarijuli 2016. Jurnal IImu dan Kesehatan 5(2). 